\title{
Pengantar Editorial: Menggagas Kajian Digital Humanities di Indonesia
}

$\mathrm{J}$ urnal Pemikiran Sosiologi yang dikelola oleh Departemen Sosiologi, Fisipol UGM hadir kembali pada Vol.3, No.1, Januari 2016. Dalam kesempatan kali ini, kami berupaya untuk mengeksplorasi tema mengenai konsep dan praktek Kajian Humaniora Digital atau Digital humanities. Alasan yang melatarbelakangi upaya ini dilandasi oleh kenyataan dimana pada awal abad ke 21 kita menyaksikan perubahan yang demikian pesat dalam transformasi teknologi informasi dan komunikasi. Perubahan ini bukan hanya berkenaan dengan berubahnya struktur dan konteks dalam masyarakat jejaring (network society), melainkan juga perubahan dalam kehidupan sehari-hari. Dalam waktu kurang dari satu dekade, kinerja internet dan mobile technology telah mengubah lanskap sosial, politik, ekonomi dan budaya masyarakat secara global termasuk di Indonesia. Berbagai perubahan sosial bahkan politik kini juga berlangsung secara cepat melalui fasilitasi medium internet dan teknologi mobile. Berkembangnya teknologi internet web2 juga telah mengubah lanskap sosial yang penting yang ditandai oleh kemunculan media sosial hampir satu windu yang lampau.

Data internet.org menunjukkan pengguna internet di Indonesia berjumlah 73 juta orang, sedangkan pengguna teknologi mobile (cellular atau handphone) sejumlah 181 juta orang pada tahun 2015. Sementara pengguna jaringan sosial media terpopuler Facebook di Indonesia diperkirakan lebih dari 70 juta orang juga di tahun 2015. Perkembangan yang demikian pesat ini telah mengubah kehidupan sehari-hari jutaan orang di seluruh dunia termasuk di Indonesia. Hal yang paling berpengaruh adalah pada bagaimana internet dan teknologi mobile telah mengambil bagian yang penting bukan hanya sebagai medium telekomunikasi, tetapi juga pada bagaimana reproduksi sosial, ekonomi dan kultural berlangsung di Indonesia. Dengan kata lain, budaya digital menjadi bagian yang tidak dapat terpisahkan sebagai bagian dari perubahan dan transformasi sosial. Sementara itu, kajian mengenai budaya teknologi (technoculture) khususnya kajian digital humanities berkembang demikian pesat sebagai respon atas perubahan lanskap ekonomi, sosial, politik dan kultural yang diakibat oleh perkembangan ICT (information communication technology) ini. Kajian budaya teknologi merupakan analisis perkembangan teknologi yang bersifat mekanis yang bertransformasi high tech dimana cakupan teknologi menjadi kepanjangan dari keterbatasan fisik manusia. Sementara itu, kajian digital humanities secara spesifik menunjuk pada perkembangan medium teknologi digital yang mempengaruhi setidaknya lima aspek kehidupan sosial. Pertama pada cara-cara manusia berkomunikasi menjadi semakin interaktif, termasuk bagaimana teknologi mengubah kehidupan sehari-hari kita, waktu yang digunakan sebagai bagian dari kerja produktif, maupun dalam menghabiskan waktu senggang (leisure time). Kedua pada cara-cara berbagi pengetahuan dimana tuntutan untuk memperoleh informasi secara terbuka menjadi menguat. Ketiga, pengorganisasisan masyarakat dan kolektivitas sebagaimana yang menjadi bagian dari hak kebebasan berekspresi dan menjadi medium demokrasi termasuk dalam mengakses berbagai bentuk persebaran 
ideologi. Keempat, perubahan dan mekanisme praktek ekonomi dengan melibatkan partisipasi sosial.Kelima, perubahan di dalam peta politik global tentang 'surveillance' atau pengawasan terhadap akses informasi, akses pengetahuan, akses pada sumber daya ekonomi, dan pertahanan. Dalam konteks inilah, kajian digital humanities menarik untuk dikembangkan sebagai bagian penting untuk merespon perubahan sosial khususnya di Indonesia.

Melalui penerbitan edisi perdana dalam bentuk OJS (Open Journal System) ini, kami telah menseleksi tujuh artikel yang membahas kelima aspek diatas dan satu review buku mengenai konsep dan praktek Digital humanities. Artikel yang pertama berkenaan dengan cyberbullying sebagai dampak pemanfaatan medium ICT dalam kehidupan sehari-hari yang dijalani oleh para siswa di sekolah menengah atas. Dalam artikel ini, dengan menggunakan metode penelitian kuantitatif, penulis, Arsa Ilmi Budiarti, menunjukkan bahwa interaksi dalam peer group menjadi variabel yang paling berpengaruh terhadap perilaku cyberbullying siswa. Artikel yang kedua berkenaan dengan akses pada pengetahuan dan informasi melalui medium ICT melalui analisis terhadap fenomena Dokter Google dimana interaksi antara dokter dan pasien dimediasikan oleh mesin pencarian (search engine) internet. Arief Priyo Nugroho penulis artikel ini menjabarkan keterbukaan akses informasi atas pengetahuan mengenai dunia kesehatan telah menjadi hal komplementer dari pelayanan kesehatan kovensional. Implikasinya adalah sumber daya informasi mengenai kesehatan menjadikan dokter bukan lagi satu-satunya pemilik informasi tentang kesehatan dan terjadi pergeseran pola mencari sehat masyarakat dari tipe konvensional beralih menggunakan media-media yang disediakan oleh teknologi informasi. Artikel yang ketiga berkenaan dengan bentuk-bentuk pengorganisasian masyarakat dan gerakan sosial yang difasilitasi oleh medium ICT. Dalam artikel ini, Wasisto Raharjo Jati membahas fenomena aktivisme politik yang berlangsung secara online dan keberadaan cyberspace melalui sosial media yang mampu mentransformasi ruang publik sebagai ruang yang berfungsi mendorong proses kesadaran politik kelas menengah. Artikel keempat yang kami seleksi mewakili aspek mengenai praktek ekonomi yang difasilitasi oleh ICT dan implikasinya secara sosiologis. Muhammad Arief Rahadian menuliskan artikel mengenai Real Money Trade (RMT), atau pembelian barang virtual dengan mata uang nyata dalam game online. Dalam studi terungkap bahwa nilai barang virtual bersifat dinamis bagi pemain game online, sehingga pemain yang awalnya berposisi sebagai pembeli dapat berubah menjadi penjual ketika barang yang dibelinya tidak lagi dinilai berharga. Artikel lain yang juga mengungkap aspek praktek ekonomi melalui pemanfaatan media sosial bagi kepentingan dunia bisnis dituliskan oleh Ambar Sari Dewi. Lebih lanjut artikel yang membahas mengenai perkembangan metode-metode penelitian untuk memanfaatkan keberadaan Big Data yang tersedia di dalam penyelenggaraan media sosial menjadi tantangan baru bagi kalangan akademisi dan bahkan bisnis untuk dieksplorasi lebih jauh. Artikel yang berkenaan dengan aspek pengawasan dan kontrol terhadap medium teknologi digital dan internet dipaparkan oleh Roikan MA yang membahas keberadaan Forum Internet sebagai embrio munculnya komunitas virtual onlineoffline sebelum berkembangnya media sosial dan hingga saat ini masih memiliki eksistensi dan pengaruh dalam memanfaatkan medium ICT sebagai kontestasi atas ruang publik. Pengaruh media sosial dan bagaimana hal tersebut 
berdampak bukan hanya pada konstruksi identitas individu tetapi juga pada bagaimana kemunculan 'masyarakat tontonan' (the spectacle society) mengontrol pola konsumsi dan bahkan produksi citra diri dibahas oleh Evania Putri R dalam artikelnya mengenai foto diri di Instagram. Artikel terakhir adalah sebuah review buku sebagai suatu pembacaan secara kritis atas buku berjudul Understanding Digital humanities atau memahami kajian humaniora digital yang disusun oleh David M Berry pada tahun 2012. Dalam review ini selain dibahas resensi isi buku dan muatan tematik juga menyodorkan perdebatan kritis mengenai penggunaan konsep dan metode Digital humanities di dalam kajian sosial humaniora dan implikasi sosiologis yang diakibatkannya.

Demikianlah sajian artikel-artikel tersebut kami hadirkan sebagai salah satu upaya terobosan untuk menggagas dan memperbincangkan konsep, metode, dan praktek mengenai kajian humaniora digital (Digital humanities) melalui beragam perspektif kajian sosial humaniora. Artikel-artikel yang kami sajikan mewakili keragaman perspektif serta metode penelitian sosialhumaniora, khususnya mendorong eksplorasi kritis yang juga dibangun dalam tradisi keilmuan dan akademik Sosiologi. Semoga bermanfaat dan dapat menginspirasi. 